Pesq. Vet. Bras. 29(4):281-285, abril 2009

\title{
Nerve endings of filliform, fungiform and vallate papillae of dorsal tongue mucosa of White-lipped peccary (Tayassu pecari): Neurohistological observations ${ }^{1}$
}

\author{
li-sei Watanabe ${ }^{2,3 *}$, Juliana Plácido Guimarães ${ }^{3}$, Sebastião Aparecido Boleta², \\ Sonia Regina Yokomizo Almeida ${ }^{2}$, Martha Maria Righeti ${ }^{2}$, Tatiana Carlesso \\ Santos $^{4}$, Maria Angélica Miglino ${ }^{3}$ and José Roberto Kfoury Junior ${ }^{3}$
}

\begin{abstract}
Watanabe I., Guimarães J.P., Boleta S.A., Almeida S.R.Y., Righeti M.M., Santos T.C., Miglino M.A. \& Kfoury Junior J.R. 2009. Nerve endings of filliform, fungiform and vallate papillae of dorsal tongue mucosa of White-lipped peccary: Neurohistological observations. Pesquisa Veterinária Brasileira 29(4):281-285. Departamento de Cirurgia, Setor de Anatomia, Faculdade de Medicina Veterinária e Zootecnia, Universidade de São Paulo, Av. Prof. Dr. Orlando Marques de Paiva 87, São Paulo, SP 05508-270, Brazil. E-mail: watanabe@icb.usp.br

The neurohistologic observations were performed using the specimens prepared by Winkelmann and Schmitt silver impregnation method. The tissues were fixed in $10 \%$ formalin solution and sections of $40 \mu \mathrm{m}$ thickness were obtained by Leica Cryostat at $30^{\circ} \mathrm{C}$. The sections of dorsal mucosa of White-lipped peccary tongue showed numerous filliform and fungiform papillae, and two vallate papillae on the caudal part. The epithelial layer revealed queratinized epithelial cells and the connective tissue papillae of different sizes and shapes. Thick nerve fiber bundles are noted into the subepithelial connective tissue of the papillae. The connective tissue of fungiform and vallate papillae contained numerous sensitive nerves fibers bundles forming a complex nerve plexus.
\end{abstract}

INDEX TERMS: Lingual papillae, tongue, sensory innervation, silver impregnation, White-lipped peccary, Pecari tajacu.

RESUMO.- [Terminação nervosa das papilas filiformes, fungiformes e valadas da mucosa dorsal da língua de queixada: observação neurohistológica.] As observações neuro-histológicas foram realizadas utilizando amostras preparadas segundo o método de impregnação por prata de Winkelmann e Schmitt. Os tecidos foram fixados em solução de formol a $10 \%$ e seções de $40 \mu \mathrm{m}$ de espessura foram obtidas em criostato Leica $-30^{\circ} \mathrm{C}$. As seções

\footnotetext{
${ }^{1}$ Received on July 14, 2008.

Accepted for publication on December 3, 2008.

2 Departamento de Anatomia, Instituto de Ciências Biomédicas, e Setor de Anatomia dos Animais Domésticos e Silvestres, FMVZ-USP, São Paulo, SP 05389-970, Brazil. "Autor para correspondência: watanabe@icb,usp.br

${ }^{3}$ Departamento de Cirurgia, Setor de Anatomia, Faculdade de Medicina Veterinária e Zootecnia (FMVZ), Universidade de São Paulo (USP), Av. Prof. Dr. Orlando Marques de Paiva 87, Cidade Universitária, São Paulo, SP 05508-270, Brazil

4 Departamento de Zootecnia, Universidade Estadual de Maringá, Av. Colombo 5790, Maringá, SP 87020-900, Brazil.
}

da mucosa dorsal da língua de queixada revelaram numerosas papilas filiformes, fungiformes e duas papilas valadas sobre a parte caudal. A camada epitelial revelou células epiteliais queratinizadas e papilas de tecido conjuntivo de diferentes tamanhos e formas foram observadas. Espessos feixes de fibras nervosas são notados no tecido conjuntivo subepitelial das papilas. O tecido conjuntivo das papilas fungiformes e valadas contêm numerosos feixes de nervos de fibras sensíveis formando um plexo nervoso complexo.

TERMOS INDEXADOS: Papila lingual, língua, inervação sensorial, queixada, Tayassu pecari.

\section{INTRODUCTION}

The dorsal sensory innervation of tongue mucosa presents a great variability from the terminal nerve endings to the regions of oral mucosa. Bernick (1952) reported the presence of nerve fibers and their according characteristics in periodontal tissues of rhesus monkey. The sensory 

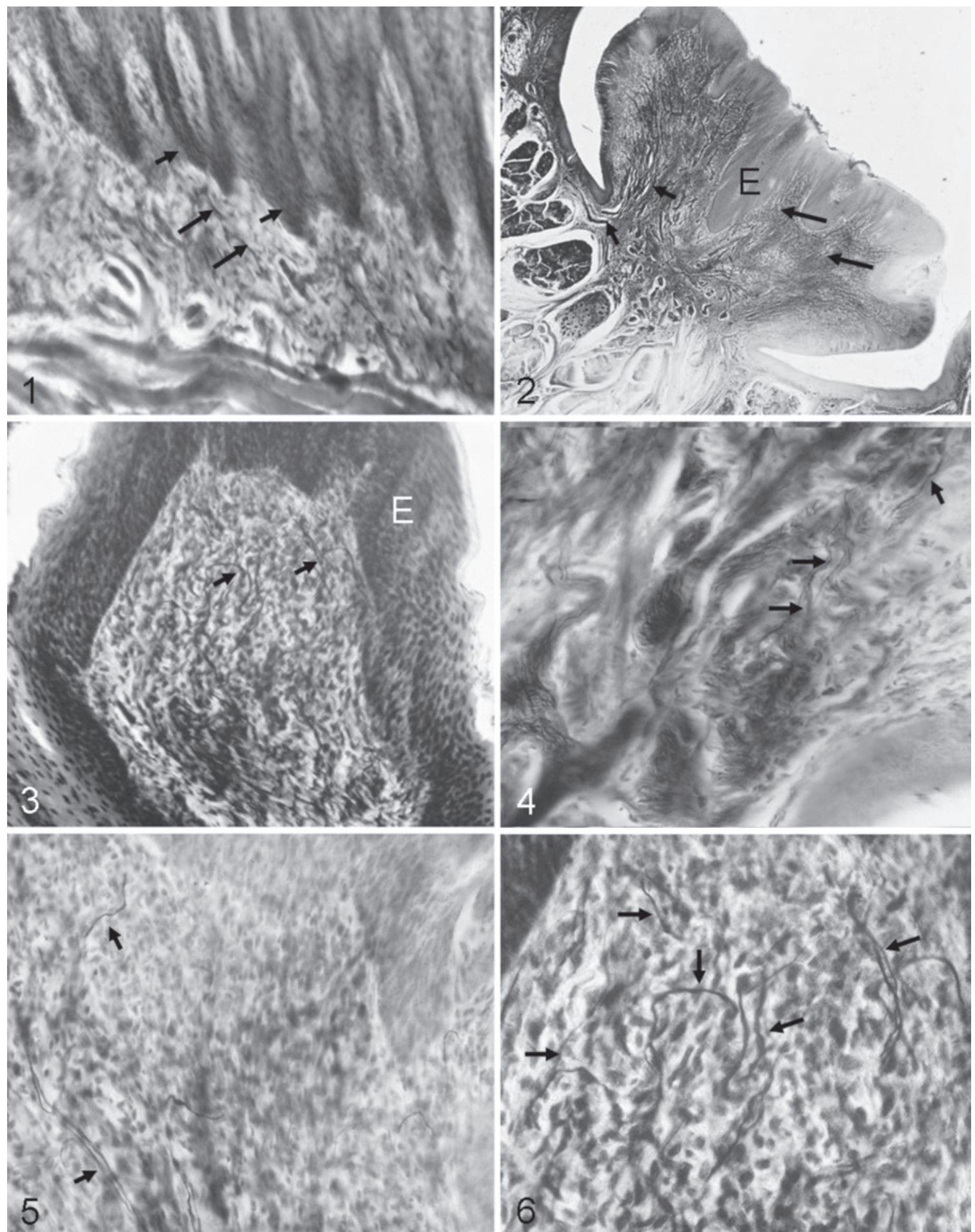

Fig.1. Frontal section of dorsal tongue mucosa of White-lipped peccary stained by silver impregnation method. The nerve fibers run in the connective tissue filliform papillae (arrows). 60x.

Fig.3. Frontal section of fungiform papilla intensely stained by silver impregnation method. The fungiform papilla $(E)$ presents numerous sensory nerve fibers running in the connective tissue (arrows). 60x.

Fig.5. The free terminal axons into the connective tissue (arrows). 240x.

Fig.2. Frontal section of vallate papilla of White-lipped peccary stained by silver impregnation method. The epithelial layer (E), connective tissue papillae (large arrows) and nerve fibers strongly stained (small arrows) are noted at the base of papilla. 60x.

Fig.4. The nerve fibers stained by silver impregnation. The fine terminal endings are noted (arrows). 150x.

Fig.6. The numerous nerve endings (arrows) into the fungiform papilla connective tissue. 240x. 

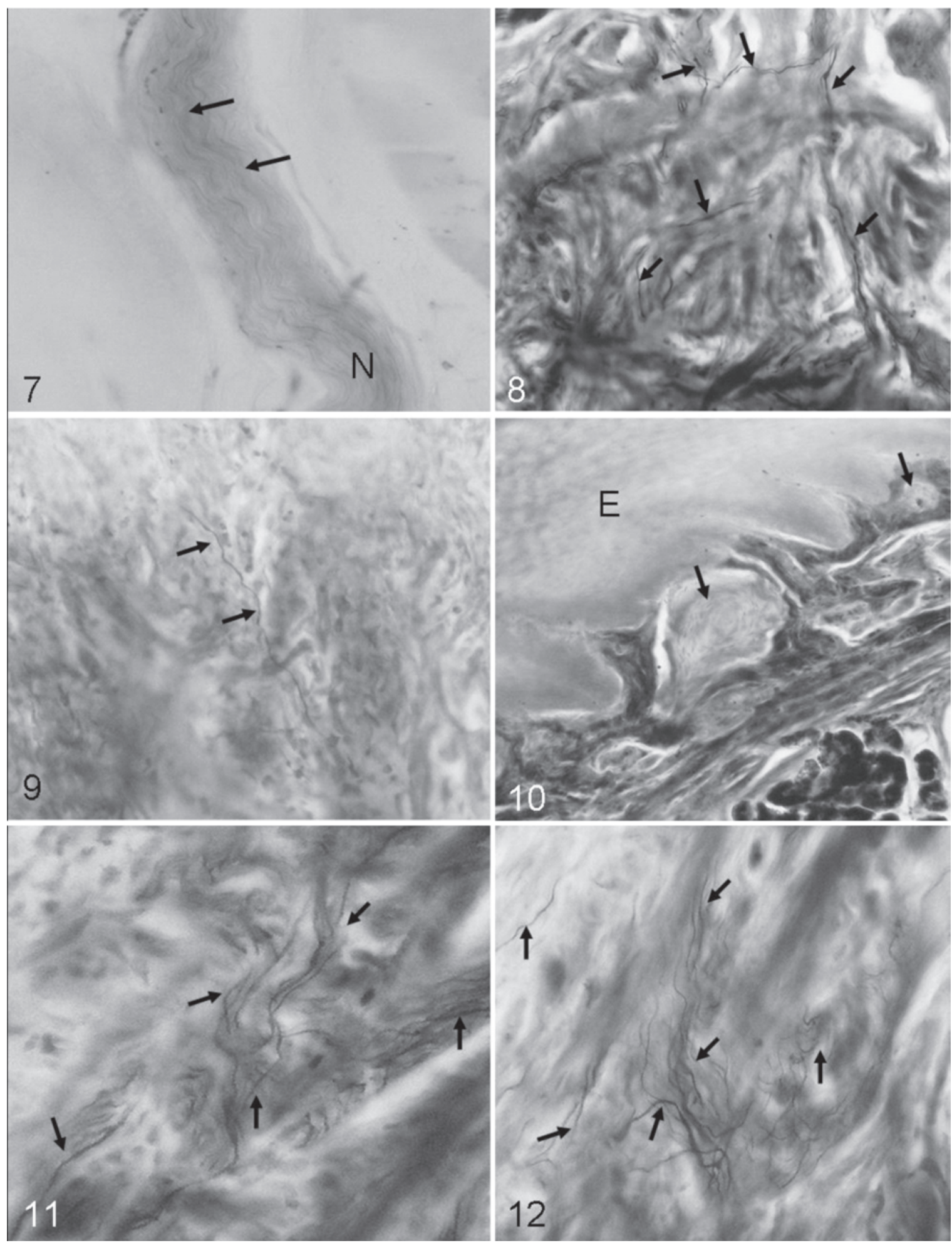

Fig.7. The thick bundle of nerve fiber located in deep layer of dorsal tongue mucosa. 150x.

Fig.9. Free nerve ending running into the connective tissue of filliform papilla (arrows). 240x.

Fig.11. Numerous fine sensory nerve endings forming a complicated plexus into the connective tissue of vallate papilla (arrows). 240x.

Fig.8. Ramifications of sensory nerve fibers into sub-epithelial connective tissue (arrows). 150x.

Fig.10. Lamellated nerve endings (arrows) at sub-epithelial connective tissue and the epithelial layer $(\mathbf{E})$ of tongue mucosa. 150x.

Fig.12. Numerous fine free nerve endings into the connective tissue of vallate papilla (arrows). 240x. 
innervation of the tongue mucosa of rhesus monkey and human were reported by Kadanoff (1971a,b,c); in Cebus apella monkey by Watanabe \& Konig (1976); in dog tongue Okano (1953) and Kikuchi (1960), and in the caudal region of swine tongue by Ohtomo (1954).

On the other hand, different types of nerve endings in the oral mucosa of mammals such as lip mucosa of cat were reported by Civarelli (1908); in the pharyngeal mucosa of cats by Kamada (1955) and Eto (1959). Kubota (1964) and Kubota et al. (1966) found sensory nerve fibers in the mouth mucosa of rhesus. The aim of this paper is to elucidate the presence of several types of sensory innervation of the dorsal surface of the tongue mucosa of White-lipped peccary especially in the filliform, fungiform and vallate papillae using the silver impregnation method.

\section{MATERIALS AND METHODS}

The samples were obtained from five animals in a wild animal slaughterhouse (Agropastoril e Criadouro Panamby Porã Ltda, Pedro Barros, SP, Brazil) authorized by IBAMA (SIF/DIPOA no.2278, IBAMA/MMA-SUP 02027.009833/97-13). The tongues were carefully dissected and fixed in $10 \%$ formalin solution for 20 days at room temperature. Then, the tissues were cut in 40$60 \mu \mathrm{m}$ thick sections under Leica Cryostat at $-30^{\circ} \mathrm{C}$. The sections were kept at $10 \%$ formalin solution for few days and processed for silver impregnation using the Winkelmann \& Schmitt (1957) method.

\section{RESULTS}

The dorsal surface of White-lipped peccary tongue mucosa presents numerous filliform papillae (Fig.1). The fungiform papillae are concentrated in the cranial and middle parts of tongue and in the two vallate papillae in the caudal region (Fig.2) exhibiting a thick epithelial layer. The cellular components are stained with silver impregnation are shown as dark lines (Fig.1 and 3).

The fine terminal endings are often present in the subepithelial connective tissue and in the papillae connective tissue. The connective tissue of fungiform and vallate papillae show numerous sensitive nerve endings (Fig. 2 and 3). The thick nerve fibers come from the deep muscle layer of tongue and, on the base of the papillae, they divided several times forming fine terminal endings (Fig.4). Figures 5 and 6 reveal the fine free nerve endings intensely stained by silver and located very close to the epithelial layer. The formation of a plexus is noted in Figure 6. Thick bundles of nerve fibers are noted in the Figure 7 . The nerve fibers ramify several times into the connective tissue layer of tongue mucosa and show numerous fine terminal endings (Fig.8).

Usually, the free nerve endings which supply the connective tissue of filliform papillae are free nerve endings (Fig.9). Organized corpuscles such as the lamellated nerve endings are noted in the subepithelial spaces very close to the epithelial cells (Fig.10). The axon is located in the central portion. The connective tissue of fungiform and vallate papillae has numerous nerve fibers forming a complicated network as shown in Figures 11 and 12.

\section{DISCUSSION}

Our results demonstrated that the dorsal surface of tongue mucosa of White-lipped peccary present numerous filliform papillae especially in the cranial part, and numerous fungiform papillae and vallate papillae in the caudal region. The histological observations after the silver impregnation method exhibited the thick epithelial layer with keratinized epithelial cells. The data revealed that the characteristic of sensory nerve fibers found in the connective tissue of fungiform and vallate papilla are similar to those reported by Nakayama (1943), Gairns (1956) and Nakai (1960) in the human tongue mucosa, by Okano (1953) in the dog's tongue, Kamada (1955) in oral mucosa of ca, Kubota (1964) in the tongue of pimy and commom marmosets, Kubota et al. (1966) in the tongue of squirrel monkeys, and by Kubota \& Iwamoto (1967) in the tongue of slow loris. The nerve fiber bundles found the sub-epithelial connective tissue of these papillae in the tongue mucosae are different from those reported by Dixon (1961), Gairns \& Aitchison (1950), Gairns (1951, 1956), and Rapp et al. (1957) in gingival mucosa.

The nerve fiber bundles encountered in the most of sections of fungiform and vallate papillae are provenient from the deep portion of the subepithelial connective tissue. These sensory nerve fibers reach the connective tissue papilla and subdivided into numerous branches which end very close to the basal epithelial cells. On the other hand, our results revealed that the nerve fiber bundles of vallate papilla present a variability of branches forming complex meshwork of sensory terminations. The presence of these nerve fibers characterizes the afferent impulse of sensitivity in the tongue mucosa of these animals.

\section{REFERENCES}

Bernick S. 1952. Innervation of the primary tooth and surrounding supporting tissues of monkeys. Anat. Rec. 113:215-27.

Civarelli I. 1908. Contributo allo studio delle terminazioni nervosa nel labio del gatto. Anat. Anz. 33:461-64.

Dixon A.D. 1961. Sensory nerve in the oral mucosa. Arch. Oral Biol. 5:105-114.

Eto S. 1959. On the sensory nerve distribution in the mucous membrane of the cavum oris and the pars nasalis pharynges of cat in the last fetal stage. Arch. Hist. Jpn. 17:569-89.

Gairns F.W. \& Aitchison J. 1950. A preliminary study of the multiplicity of nerve endings in the human gum. Dent. Pract. 70:180-94.

Gairns F.W. 1951. Nerve endings in the human gum and hard palate. J. Physiol. 115:70.

Gairns F.W. 1956. The sensory nerve endings of the human gingival, plate, and tongue. J. Dent. Res. 35:948.

Kadanoff D. 1971a. The endings the nerve fibers in the taste buds of monkeys as compared with human. Z. Mikr.-Anat. Forsch. 81:295303.

Kadanoff D. 1971b. Morphology of nerve terminals in the lingual mucosa of the rhesus monkey as compared to that of the human. Z. Mikr.Anat. Forsch. 82:445-60.

Kadanoff, D. 1971c. The network of nerve fibers in the vallate and fungiform papillae of the tongue in primates. Z. Mikr.-Anat. Forsch. 83:321-30. 
Kamada S. 1955. On the innervation specially sensory innervation of mucous membrane of the oral cavity of cat. Arch. Hist. Jpn. 8:243-60.

Kikuchi M. 1960. On the nerve supply of the dorsum linguae and the facies inferior linguae in newborn dog. Arch. Hist. Jpn. 19:310-31.

Kubota K. 1964.Comparative anatomical and neurohistological observations on the tongues of the pigmy and commom marmosets. Anat. Rec. 150:473-86.

Kubota K., Hayama S. \& Iwamoto M. 1966. Comparative anatomical and neurohistological observations on the tongue of squirrel monkey. Primates 7:381-89.

Kubota K. \& Iwamoto M. 1967. Comparative anatomical and neurohistological observations on the tongue of slow loris. Anat. Rec. 158:163-176.

Nakai R. 1960. Supplement to the histological observation on the sensory nerve supply of the human tongue. Arch. Hist. Jpn. 20:161-78.
Nakayama T. 1943. Histological studies on the nerves in human tongue papillae especially on the sensory nerve endings. Tohoku Igaku Zassi 33:473-85.

Ohtomo N. 1954. Innervation of radical part of tongue of hedgehog. Arch. Hist. Jpn. 7:71-82.

Okano S. 1953. Innervation especially sensory innervation of dog tongue. Tohoku J. Exp. Med. 57:169-79.

Rapp R., Kirstine W.D. \& Avery T.K. 1957. A study of neural endings in the human gingival and periodontal membrane. J. Canad. Dent. Assoc. 23:637-43.

Watanabe I. \& Konig Jr B. 1976. Neurohistologic observations of the Cebus apella monkeys soft palate mucosa. Revta Bras. Pesq. Med. Biol. 9:179-82.

Winkelmann R.K. \& Schmitt R.W. 1957. A simple silver method for nerve axoplasm. Proc. Staff. Meet. Mayo Clin. 32:217-22. 